\title{
Emancipating Domestic Workers: Challenges, Interventions and Prospects
}

\author{
Kola O. Odeku \\ Faculty of Management and Law, School of Law, \\ University of Limpopo, South Africa \\ Email: kooacademics@gmail.com
}

\author{
Doi:10.5901/mjss.2014.v5n8p672
}

\begin{abstract}
Undoubtedly, domestic work falls under the ambit of employment and as such, there are people, who will, based on one reason or another engage in it and perform the job. More importantly, national and international instruments in some countries have been put in place to specifically recognise and protect domestic workers and the jobs they do. However, in spite of this, domestic workers are still being violated and abused by employers in various ways. This therefore, raises the issues whether they have, despite various interventions been emancipated or not? Against this background, this paper seeks to look at the challenges hindering emancipation in spite of the interventions that have been made to improve the standard of the employees in the sector.
\end{abstract}

Keywords: Domestic work force, Discrimination, Wages, Women and Children. Interventions.

\section{Introduction}

A large number of domestic workers are women mostly from developing countries (le Roux, 2013). In South Africa, domestic work force is (Klasen and Woolard, 2009) predominantly dominated by black women (Gaitskell et al. 1983). Confirming this assertion, Gaitskell et al. (1983) write "domestic service has long been a major sector of the South African labour market, for black women." The reason why majority of the black women engage in domestic works and services is not farfetched. The brutal Apartheid regime that existed before the advent of constitutional democracy in South Africa disadvantaged the black people and placed restrictions on the types of jobs they were eligible to engage in (Wing and de Carvalho 1995). Hence, they resort to domestic labour being the only job that does not require any skill to venture into. Towards this end, most of them were exploited and had no legal protections other than the common law, they worked under terrible and dehumanizing conditions and were also subjected to various racial and sexism abuses (Cole, 1992). They were denied and deprived of ample education that would have emancipated them and placed them on the same footing with their white counterparts (Fiske and Ladd, 2004). As a result of this denial, domestic workers have no other hope of prospects for decent jobs or accommodation except to work as domestic workers, for the house holders and perform undesirable dirty jobs (Ally, 2011). Sometimes called house maids, they earn meager non-living wages as income and provide services including but not limited to looking and caring for their employer's children, acting as gardener, cleaning, cooking and providing other services (Kilbride et al. 2006). Sometimes some of them have no roofs over their heads hence they accepted the accommodation incentives offered by the masters to live in the space in the backyard rooms, and permanently become the family maids (Ginsburg, 2000). These and other sources of disempowerments were used by the regime to suppress the black majority and made them ordinary citizens in their fatherland (Clark and Worger, 2013). In order to fend for themselves and family, one of the attractive jobs available to them was to work as domestic workers where they will have to be subordinate to and serve the masters and the madams (Ally, 2011). Even with the advent of nascent democracy, the situation of domestic workers has only changed with regard to issues of wages but abuses, maltreatment and unfair labour practices are still prevalent (Atkinson, 2007). Magwaza (2008) study revealed that "although domestic workers comprise a significant portion of the working class...despite the fact that more than one million people are employed as domestic workers in private households. Women dominate this sector of the labour market and this may have contributed to shunning of the domestic sector."

In South Africa, the advent of democracy gave everyone the right to a fair labour practice (Govender, 2006.). However, to a large extent, despite constitutional mandate compelling fair labour treatment and insisting on the dignity for all including vulnerable workers such as domestic workers, and other pieces of legislation regulating domestic works, domestic workers (in particular, those previously disadvantaged and deprived from the informal settlements and rural areas) are still faced with contemptuous discriminations of all sorts wherever they find themselves (du Toit, 2013). To the 
employers, the domestic workers should be grateful that the employers have provided jobs and live-in accommodation for them otherwise they would be jobless and have no source of livelihood or survival (Braybon, 2012). Most times, domestic workers are underpaid, deprived of the right to minimum living wage and sometimes maltreated especially when they are live-in (Hiller and Saxtein, 2009; Anderson, 2000). As migrant workers, they are perpetually exploited, harassed and intimated by threats of deportation by their employers. (Shelley, 2007). Worst still, some employers use children who are supposed to be in school as domestic workers (England and Stiell, 1997). Therefore, the concern is that the vulnerable groups such as women and children are still being used for domestic works and subjected to various ill-treatments and abuses in the workplace (Budlender and Bosch, 2002). This is a confirmation of perpetration of gender discrimination and inequality. While these practices were perpetrated under the brutal apartheid regime, sadly, these abuses have outlived the apartheid regime and are still being perpetrated in the post-apartheid era in South Africa (Gobodo-Madikizela, 2004). The affluent black elites and the middle class in the townships have now joined their white counterparts as the new masters and madams (Dilata, 2008). The study conducted by Dilata (2008) revealed that "the employment relationship that African employers have with their domestic workers is not different from the traditional relationship between white employers and African domestic workers, as African employers reproduce some of the exploitation that existed in the sector. Despite legislative rights being awarded to domestic workers, a number of the domestic workers in the townships are still being paid below minimum wage, have no set working hours and work without any written contracts of employment. The study also revealed the use of the term 'helper' by African employers, as a way of building unity and equality in the relationship that they have with their domestic workers. The study concludes by suggesting that there is a need for a more forceful approach from government in ensuring that employers comply with the law." Du Toit (2010) notes and asserts that "the multi-layered nature of the inequality embodied by the relationship has continued."

\section{Literature Review}

Domestic workers are being used for works which are sometimes dirty and dehumanising in virtually all countries but more rampant in the developing counties (Swanson, 2001). Majority of them are women form poor backgrounds (Niedzviecki, 2013). Souza (2010) observed that "domestic work is a predominately female-dominated sector that is poorly regulated and often unprotected by labour law. It is also often embedded within sociocultural structures, which may make it difficult for employers to see themselves as such. Moreover, issues of gender, class, ethnicity and caste also come into play heightening the weak bargaining power of domestic workers."

According to Kit (2013) "domestic workers are workers employed by private households within national boundaries or overseas to do house chores and care work. They constitute an integral part of the labour force worldwide. According to ILO data, the estimates are $4-10 \%$ of the labour force in developing countries and about $2 \%$ of the workforce in developed countries" (Kit, 2013).

The position of the International Labour Organisation (ILO) on the relatively high number of domestic workers is that "on the supply side rural poverty, gender discrimination in the labour market as well as limited employment opportunities in general in rural communities and countries of origin ensure a continuous supply of workers into the sector" (D'Souza, 2010).

While it is considered appropriate to continue to allow some people to provide household care and management to others, the argument has always been that government the state should put in place and ensure adequate regulatory frameworks to protect domestic workers (Peck, 1996). It must be emphasized that the move towards emancipation of domestic workers is evolving and now making waves, this is the reason why Blackett (2011) notes that "the literature on labour regulatory strategies to assist in the transformation of the domestic work relationship is only recently starting to emerge, in large measure because of a long-awaited initiative to develop an international labour standard on "decent work for domestic workers." The situation in Ghana is appalling because domestic work is not regulated as pointed out by Tsikata (2009) where he stressed that "while there have been studies of domestic work as well as reforms of its legal framework worldwide, this type of work continues to be largely invisible and unregulated in Ghana." In the USA, the state at some point had to use human rights standards and norms to address the plights of domestic works in order to offer them protection (Satterthwaite, 2008). In Canada, "transnational migrant domestic workers who perform work on a live-in basis in Canadian homes cross a number of jurisdictional boundaries-between different nation states, different areas of law, and different levels of government within a nation. This "transgression" makes it difficult to govern these workers in a manner that provides decent work" (Fudge, 2011).

The general consensus amongst scholars and activists is that there should be ample protection for domestic workers, the work should be decent and humanized, they should be treated with dignity just like any other person providing services and earn decent living wages (Inglis, 2001). Decent work for domestic workers "once regarded as an 
obsolete occupation, domestic service continues to grow, as increasing numbers of workers enter into the homes of others to perform a range of services for pay including cooking, cleaning, laundry, childcare, care of the elderly, gardening, and shopping. Domestic work is one of the fastest growing economic sectors in many parts of the world" (Smith et al. 2011).

Domestic workers play vital roles in the household, they fill the gap created by the unavailability of the career women in the house by performing jobs and hitherto performed by the career women (Yeoh and Huang, 1999). This observation is well articulated by Smith et al. (2011) by saying that "the dramatic increase in the demand for domestic workers across the globe reflects a host of sea changes including the steady movement of women into the paid labour force, the ageing of the population, and the inadequacy of policies to enable workers to better balance the pressures of work with their familial obligations. Domestic service is vital not only because it helps families to satisfy their household needs but also because it facilitates the participation of family members in economic and other activities outside of the household. Domestic workers are in many ways "oil for the wheels of the economy."

Tomei (2011) study of the situation in Belgium, France, the Canton of Geneva in Switzerland, and Brazil show that "a growing involvement of the state and the market in the regulation and supply of domestic services offers an avenue for delivering decent work for domestic workers and challenges the historical undervaluation of their work...and these systems help regularize casual and part-time domestic work but are less effective in stabilizing hours of work and labour earnings, countering the isolation of domestic workers, and providing them with opportunities to further upgrade their skills and competencies."

\section{Challenges Hindering Emancipation of Domestic Workers}

Domestic workers in South Africa are unique in some sorts because they have had the experiences of working as domestic workers pre and post-apartheid South Africa ( Worden, 2011). Under apartheid, they were regarded as paid workers but the relationship was that of servitude not employer and employee relationship hence they had limited or no legal protections under the law (Blackett, 20112). Under the new democratic South Africa, they now enjoy extensive rights as workers and are recognized under the law (Ally, 2011). However, the extent at which they now benefit from the rights in form of entitlement is still far from being realised. To a greater extent, their rights are constantly being violated by the employers because of the vulnerable status of those who engage in the work (Grant, 1997). Pursuant to this, even though there are protective mechanisms for them, the dilemma is that majority of them are yet to be emancipated and they are still constantly being abused and violated in spite of the modernization of the occupation through state-based regulation (Theron, 2003).

Domestic work is well entrenched and the practice continues from generation to another generation (Rittich, 2004). It reflects class differentiation and prices one job as valuable over and above others (Wright, 1997). The job makes those who perform it to be perpetually subdued and oppressed (Anderson, 2000). They are mostly subjected to the dictates of the house holders and most times, they do not have any say in the employment relationship (Marglin, 1996). This type of inequality is elaborately articulated by Du Toit (2010) and asserted that "the vast majority of domestic workers are poorlypaid African or coloured women, singled out for this role, as it were, by the coincidence of their class, race and gender. In this sense domestic employment remains an institution with roots deeply embedded in colonial society, regardless of the identity of the employer. Seeking to abolish its oppressive characteristics means addressing not only patterns of behaviour that have become established over centuries but also the (self) perceptions that have been generated and have become equally deeply-rooted."

One striking characteristic of domestic work is the perception that paid domestic work "is a form of servitude within South Africa's modernizing racial capitalism. The work reproduced the racialised logics of apartheid that construed blacks as a servant class and socialized white South Africans into the attitudes of racial domination necessary for its distinctive racial modernization"(Ally, 2011).

Domestic workers are assigned to do house chores and other menial jobs in their masters' homes which allow their employers to engage in accumulating other forms of capitals, including cultural, while limiting domestic workers' ability to engage in these 'value-added activities themselves (Dangler, 1994). The implication of this is that through household work, the multiple axes of inequality dividing household workers and employers intensify and hardened (Romero, 2002).

A lot of interventions in terms of policies and laws have been introduced and put in place by various governments to regulate and monitor domestic work sector. The recognition of the right of domestic workers to dignity and living wage is therefore a step towards ensuring that their employers treat them with absolute dignity they deserve just like any other human being or person performing or undertaken a job at any workplace (Budd, 2004). While this is commendable, it is important to point out that the reality physically on the ground does not reflect the contents and spirits of all the 
intervening national and international instruments that talk directly on how domestic workers should be treated in the workplace. Pursuant to this, the purport and intention to emancipate them are now being hampered by various challenges created mostly by the employers and these are the major stumbling blocks to the realization of the right to dignity and fair labour practice. Due to lack of proper oversights by the governments, this devalues "the economic and social contribution of domestic work to development, it exacerbates abuse and exploitation of workers. This includes: contract substitution, poor wages, non-payment or delayed payment of wages, very long hours of work, no break periods or rest days, restrictions on freedom of movement and association, no access to collective bargaining, inadequate food and accommodation, including lack of privacy, sexual and gender-based violence" (Kit, 2013).

Notable challenges hindering emancipation of domestic workers are that the works they do are "invisible and conducted within the private space of the home - not defined as a "workplace". It also carries the low value of women's unpaid housework, not defined as work, because it is not perceived as producing value. Domestic work is in fact seen as a "labour of love" or part of women's innate attributes, needing no special skill. The special bonds of attachment that may develop between employers, domestic workers, and family members being cared for, complicates an understanding of domestic work as work that needs regulation" (Kit, 2013).

Souza (2010) writes that "domestic workers themselves often work long hours, have poor remuneration, and little access to social protection. Their isolation and vulnerability as workers is made more complex by their invisibility in private homes and their dependence on the good will of their employers. Many, though not all, come from poor households, often in rural communities, where limited access to education and skills development, leave them with few employment opportunities and choices. Others, especially those migrating abroad, may be skilled, yet unable to find employment commensurate with their levels of education."

The concern is that "despite its importance, however, domestic service remains an economically marginalized job that subjects its workers to abuse and exploitation. As one commentator observed, Domestic service is [both] vital and sustaining, and demeaned and disregarded. This seeming paradox hinges heavily" (Smith et al. 2011).

\section{Prospects made so far to Emancipate Domestic Workers}

It is generally perceived that "domestic work contributes to renewing and sustaining life and is critically linked to social and economic development" (Kit, 2013). In South Africa, paid domestic work is recognized as a form of employment and their rights are well enshrined and recognized in the existing pieces of labour legislation (Trebilcock, 2005). By recognizing this work like any others, the government is asserting that it is a form of work that should be accorded the same respect and dignity by formalizing, modernizing and professionalizing it as a form of employment (Ally, 2011). Therefore, domestic work plays a vital role in the economy growth and development (Boserup et al. 2013). The concern is that when the employer treats the worker badly by violating the right to dignity, it then becomes demeaning and degrading (Dilata, 2008). While this is a pitfall, the prospect/intervention is that "labour laws covering domestic workers have been introduced and implemented in several countries over the years. These include Argentina, Bolivia, Brazil, Chile, France, Hong Kong, SAR, Jordan, South Africa, Spain, Switzerland, Uruguay, some US states and others. These initiatives are in line with international human rights standards, including the recently adopted ILO Convention 189 and Recommendation 201 on Decent Work for Domestic Workers, 2011; the General Comment on Migrant Domestic Workers by the Committee on the Protection of the Rights of All Migrants and Members of their Families (CMW), 2010; the Convention on the Elimination of All Forms of Discrimination against Women (CEDAW), and its General Recommendation No 26 on Women Migrant Workers (including domestic workers)" (Kit, 2013).

Grant (1997) points out "that the continued vulnerability of women in the domestic sector has layers of colonial and racial oppression to blame. Unions and the law have still to protect domestic workers against some of the most exploitative labour practices in the workplace of the home." It is important to point that there is now black oppression and this is also to blame (Collin, 1997). Modern day black affluent elites and middle class are becoming more oppressive toward domestic workers and the Union should not lose sight of this (Pattillo, 2013).

Tome (2011) looks at other approaches that can be utilised to ensure that decent works and wages are given to domestic workers and indicates that "recent attempts to curb the incidence of informal domestic work include simplified payment procedures for employers, state incentives (for example, tax credits), and the "industrialization" of domestic work (for example, the creation of licensed enterprises that provide domestic services to client households) (Tomei, 2011).

In South Africa, one of the strides made was the introduction of the Sectoral Determination Seven of the Basic Conditions of Employment Act ( Magwaza, 2008). Pursuant to this, employers of domestic workers, labour unions and activists engage in robust debates on the issues surrounding decent work and wages for domestic workers (Brites, 2013). To a larger extent, a number of domestic workers now know their rights and can approach appropriate tribunals and 
institutions to lodge complaints of unfair labour practice and other labour disputes arising from their employments (Magwaza, 2008).

\section{Conclusion}

While attempts have been made through introduction of numerous laws and initiatives to offer protections for domestic workers, majority of them are still yet to be emancipated. The reasons for these are numerous. They work in strict regulatory environment under the instruction and command of the employers. Because it is an informal job, they are vulnerable as their services are at the mercy of the employers. The employers dictate and call the shots and consider the domestic worker opportune to have even been given a job knowing that the worker has no skill or expertise to be employed in another vocation. . Providing and putting in place regulations and legislation are not enough; more still need to be done in terms of implementation and monitoring of the application of the laws. The laws should be seen to have physical impacts wherever domestic workers are providing services. This is how their rights and dignity will be respected and protected.

\section{Recommendations}

Under the enabling laws, in most cases, the domestic workers have the right to damages for wrongs. There are situations where domestic workers are physically assaulted and abused, but most of these vulnerable workers are too timid to lodge complaints for fears of reprisals and dismissal by the boss. The workers should be educated and sensitised of their rights which include the right to lodge complaints to the appropriate law enforcement agents in order to hold the perpetrators of these criminal acts criminally and civilly accountable. The labour unions need to accept domestic workers as members and offer them the same protections being offered to workers in formal sectors. This will give the vulnerable domestic workers sense of belongings and dignified their work because of equal recognition. More importantly, any form of modern en-slavery such as failure to pay minimum living wages, racial abuses, child labour and so on should be prohibited and perpetrators should be held accountable by bringing them to justice.

\section{References}

Ally S 2011. From servants to workers: South African domestic workers and the democratic state. Cornell University Press, New York, USA.

Anderson B 2000. Doing the dirty work?: the global politics of domestic labour. Zed Books Ltd, London, UK.

Atkinson D 2007. Going for broke: The fate of farm workers in arid South Africa. From hsrcpress.ac.za. (Retrieved July 9, 2013).

Blackett A 2011. Introduction: Regulating decent work for domestic workers. From http://utpjournals.metapress.com/content 172742629063802q3/fulltext.pdf. (Retrieved February 15, 2014).

Boserup E, Tan SF, Toulmin C 2013. Woman's role in economic development. http://books.google.co.za/books?hl=en\&lr= \&id=nv7ingskXC4C\&oi=fnd\&pg=PP2\&dq=. (Retrieved May 6, 2014).

Braybon G 2012. Women Workers in the First World War. Routledge, New York, USA. Brites JG 2013. Domestic work: issues, literature and policies. From http://www.scielo.br/scielo.php?pid=S0100-15742013000200004\&script=sci_arttext.(Retrieved February 4, 2014).

Budd JW 2004. Employment with a human face: Balancing efficiency, equity, and voice. Cornell University Press, New York, USA.

Budlender D, Bosch D 2002. South Africa: Child Domestic Workers: a National Report. From http://www.anexcdw.org.za/attachments larticle/39/CDW\%20-\%20SA\%20REPORT.pdf. (Retrieved June 1, 2013).

Clark NL, Worger WH 2013. South Africa: The rise and fall of apartheid. Routledge, New York, USA.

Cole M 1992. Inthuthuko Means That We Are Going Forward: Hearing the Voices of Domestic Workers in South Africa. Columbia Journal Gender \& Law, 2:61-72.

Collins PH 1997. Toward a new psychology of gender. Routledge, New York, USA.

Dangler JF 1994. Hidden in the home: The role of waged homework in the modern world-economy. State University of New York Press, Albany, USA.

Dilata XP 2008. Between 'Sisters': A study of the employment relationship between African domestic workers and African employers in the townships of Soweto. Routledge, New York, South Africa.

Dilata XP 2008. Between 'Sisters': A study of the employment relationship between African domestic workers and African employers in the townships of Soweto. From http://mobile.wiredspace.wits.ac.za/handle/10539/7611. (Retrieved January 5, 2014).

D'Souza A 2010. Moving towards decent work for domestic workers: An overview of the ILO's work. From http://courses.itcilo.org /A906119/documentation/ilo-studies-papers/Moving\%20towards\%20DWDW\%200verview\%20of\%20ILOs\%20work.pdf. (Retrieved June 16, 2013).

Du Toit D 2010. Extending the frontiers of employment regulation: The case of domestic employment in South Africa. Law, Democracy \& 
Development, 14:1-27.

du Toit $D$ 2013. Integrated model for the regulation and enforcement of domestic workers' rights. From http://www.pulp.up.ac.za/pdf 12013_11/2013_11.pdf\#page=329. (Retrieved April 4, 2014).

England K, Stiell B 1997. They think you're as stupid as your English is: constructing foreign domestic workers in Toronto. Environment and Planning, 29:195-215.

Fiske EB, Ladd HF 2004. Elusive equity: Education reform in post-apartheid South Africa. Brookings Institution, Press, Washington, USA.

Fudge J 2011. Global care chains, employment agencies, and the conundrum of jurisdiction: Decent work for domestic workers in Canada. Canadian Journal of Women and the Law, 23(1): 235-264.

Gaitskell D, Kimble J, Maconachie M, Unterhalter E 1983. Class, race and gender: domestic workers in South Africa. Review of African Political Economy, 10(27-28):86-108.

Ginsburg R 2000. Come in the Dark": Domestic Workers and Their Rooms in Apartheid-Era Johannesburg, South Africa. Perspectives in Vernacular Architecture, 8:83-100.

Gobodo-Madikizela P 2004. A human being died that night: A South African woman confronts the legacy of apartheid. Houghton Miffin Company, New York, USA.

Govender K 2006. Assessing the constitutional protection of human rights in South Africa during the first decade of democracy. Human Sciences Research Council, Cape Town, South Africa.

Grant B 1997. Domestic workers employees or servants? Agenda: Empowering women for gender equity. The Labour Market, 13(35): 61-65.

Hiller AJ, Saxtein LE 2009. Falling through the Cracks: The Plight of Domestic Workers and Their Continued Search for Legislative Protection. Hofstra Labour \& Employment Law Journal, 27:233-242.

Inglis SC 2001. Expanding International and National Protections against Trafficking for Forced Labor Using a Human Rights Framework. Buffalo Human Rights Review, 7:55-64.

Kilbride KM, SM Webber, C Wong 2006. Plug them in and turn them on: Homelessness, immigrants, and social capital. From http://www.homelesshub.cal(S(2cz1ye55etzrt145eemclOyi)X(1))/ResourceFiles/005_EN_Plug_Them_In_and_Turn_Them_OnFinal_Ryerson_R.pdf. (Retrieved on March 11, 2013).

Kit $A B$ 2013. Domestic workers count too: for domestic workers. From http://www.migration-unifem-apas.org/docs IDomestic_workers_Count_Too.pdf. (Retrieved February 4, 2014).

Klasen S, Woolard I 2009. Surviving unemployment without state support: unemployment and household formation in South Africa. Journal of African economies, Journal of African Economics, 18 (1): 1-51.

le Roux W 2013. Advancing domestic workers 'rights in a context of transformative constitutionalism: undervalued-and essential: domestic. Pretoria University Law Press, Pretoria, South Africa.

Magwaza T 2008. Effects of Domestic Workers Act in South Africa: A steep road to recognition. Engendering National \& Global Economic Policies, 22 (78):79-92.

Marglin SA 1996. What do bosses do? - Radical Political Economy: Explorations in Alternative Economics Analysis. M.E. Sharpe Incoporation Publishers, New York, USA.

Pattillo M 2013. Black picket fences: Privilege and peril among the black middle class. The University of the Chicago Press, Chicago, USA.

Rittich K 2004. Future of Law and Development: Second Generation Reforms and the Incorporation of the Social. Michigan Journal of International Law, 26:199-2011.

Romero M 2002. Maid in the USA. Routledge, New York, USA.

Trebilcock A 2005. Decent work and the informal economy. From http://www.econstor.eu/handle/10419/52876. (Retrieved May 16, 2012).

Wright EO 1997. Class counts: comparative studies in class analysis . Press Syndicate of the University of Cambridge, New York, USA.

Niedzvieck H 2013. The peep diaries: How we're learning to love watching ourselves and our neighbors. City Lights Books, California, USA.

Peck J 1996. Work-place: The social regulation of labor markets. Guilford Press, New York, USA.

Satterthwaite ML 2008. Using Human Rights Laws to Empower Migrant Domestic Workers in the Inter-American System- New Perspectives on Gender and Migration. UNRSD Publication.

Shelley T 2007. Exploited: migrant labour in the new global economy. Zeb Books, Ltd. London, UK.

Smith PR 2011. Work Like Any Other, Work Like No Other: Establishing Decent Work for Domestic Workers. Employment Rights \& Employ Policy, 15:159-168.

Swanson J 2001. Poor-bashing: The politics of exclusion. Canada Council for Arts Publication, Toronto, Canada.

Theron J 2003. Employment is not what it used to be. Industrial Law Journal, 24:1247-252.

Tomei M 2011. Decent work for domestic workers: Reflections on recent approaches to tackle informality. Canadian Journal of Women and the Law. 23(1):185-212.

Tsikata D 2009. Domestic Work and Domestic Workers in Ghana: An overview of the legal regime and practice. From http://www.llo.int/wcmsp5/groups/public/---ed_protect/---protrav/---travail/documents/publication/wcms_145332.pdf. (Retrieved September 4, 2013).

Wing AK, de Carvalho E P 1995. Black South African Women: Toward Equal Rights. 8 Harvard Human Rights Journal, 8:57-68.

Worden N 2011. The making of modern South Africa: conquest, apartheid, democracy. John Wiley \& Sons, West Sussex, UK.

Yeoh BSA, Huang S 1999. Spaces at the margins: migrant domestic workers and the development of civil society in Singapore. From http://envplan.com/epa/fulltext/a31/a311149.pdf. (Retrieved January 8, 2013). 
This journal is printed for MCSER

By Mediagraf SPA

Via Leonardo da Vinci, 8, (RM)

Telefono: +390643560502

Fax: +390643534468

E-Mail:info.rm@mediagrafspa.it 